IMEJ: Islamic Management and Empowerment Journal

Volume 2, Number 2, Desember 2020. p. $183-202$

P-ISSN:2685-953X; e-ISSN:2686-0317

DOI: $10.18326 /$ imej.v2i2.183-202

website: http://e-journal.iainsalatiga.ac.id/index.php/imej

\title{
Bahasa dan Community Development: Pergeseran Penggunaan Bahasa Daerah Sebagai Dasar Pemberdayaan Masyarakat Dalam Ruang Pendidikan
}

\author{
Lenni Yati Sagala \\ MTs Negeri 2 Labuhanbatu Selatan, Provinsi Sumatera Utara,Indonesia \\ sagalalenniyati@gmail.com
}

\author{
Azhar Riyadi \\ Kementerian Desa, Pembangunan Daerah Tertinggal, dan Transmigrasi, \\ Indonesia \\ azharisagala@gmail.com
}

\begin{abstract}
This article is intended to explore how students at MTsN 2 Labuhanbatu Selatan practice their daily language. The use of everyday language in the education space is the basic asset for community development programs. The data in this study were obtained by using questionnaires and interviews, The data shows that in families and schools students make Indonesian the first language and local languages as the second language. The study results confirm that this causes these roles to be replaced by informal roles. So that students can speak the local language but shallow the understanding of the values contained in the language. It is necessary to strengthen cultural and formal institutions to encourage the promotion of regional languages with a multicultural approach for the sustainability of regional languages. So that in the long term, the existence of regional languages continues to develop as an initial provision for community development.
\end{abstract}

Keywords: Practice Speaking; Local Languages; Community Development; South Labuhanbatu; Multicultural.

\begin{abstract}
Abstrak
Artikel ini dimaksudkan untuk mengeksplorasi bagaimana siswa di MTsN 2 Labuhanbatu Selatan mempraktikkan bahasa sehari-harinya. Penggunaan bahasa sehari-hari dalam ruang pendidikan adalah modal dasar bagi program pengembangan masyarakat. Data dalam studi ini diperoleh dengan metode angket dan wawancara. Data memperlihatkan bahwa dalam keluarga dan sekolah siswa menjadikan Bahasa Indonesia sebagai bahasa pertama dan Bahasa daerah sebagai bahasa kedua. Hasil studi menegaskan bahwa hal ini menyebabkan peran-peran tersebut digantikan oleh peran-peran informal. Sehingga siswa bisa berbahasa daerah namun dangkal akan pemahaman nilai yang terkandung dalam bahasa tersebut. Perlunya penguatan institusi kultural dan formal untuk mendorong promosi bahasa daerah dengan pendekatan multikultural demi keberlangsungan bahasa daerah. Sehingga dalam jangka panjang, eksistensi bahasa daerah tetap berkembang sebagai bekal awal pengembangan masyarakat.
\end{abstract}

Kata Kunci: Praktik Berbahasa; Bahasa daerah; Labuhanbatu Selatan; Multikultural 


\section{Pendahuluan}

Praktik berbahasa tentu tidak lepas dari konteks sosiokultural masyarakatnya, seperti yang dipraktikkan oleh siswa Madrasah Tsanawiyah Negeri (MTsN) 2 Labuhanbatu Selatan tentu tidak dapat kita lepaskan dari konteks masyarakat Labuhanbatu Selatan (Labusel). Kondisi masyarakat Labusel yang heterogen dan multikultural memberi pengaruh terfragmentasinya bahasa yang digunakan dalam masyarakat (Tondro, 2009). Namun sekalipun demikian, keharmonisan akan lebih mudah tercapai dalam masyarakat yang multikultural, karena multikulturalisme telah memberi ruang bagi toleransi dan pengakuan atas perbedaan-perbedaan yang dalam masyarakat (Ali, 2016). Dalam konteks Labuhanbatu Selatan, masyarakat beretnis Batak Angkola-Mandailing yang dipandang sebagai penduduk asli senantiasa menggunakan bahasa daerahnya dalam berkomunikasi sesamanya. Sedangkan masyarakat pendatang khususnya beretnis Jawa yang merupakan etnis pendatang terbesar, umumnya tinggal di kawasan perusahaan perkebunan juga mempraktikkan bahasa Jawa dalam interaksinya. Sehingga dalam pergaulan lebih luas, bahasa yang digunakan adalah bahasa Indonesia dengan disisipi oleh beberapa kosa kata bahasa daerah dari masingmasing kelompok etnis, selain itu, peran MTsN 2 Labuhanbatu Selatan sebagai lembaga pendidikan tentu memberi pengaruh pada terbentuknya suatu keharmonisan dalam masyarakat multikultural melalui pendidikan karakter (Rasimin, 2016).

Labusel sebagai daerah yang multi etnis dan tidak memiliki bahasa yang benar-benar dominan. Walaupun dalam studi ini terlihat bahwa etnis Batak Angkola-Mandailing sebagai siswa yang dominan yakni 67,02 \%, tetapi unsur Jawa juga angkanya cukup besar yakni 20,21 \%. Artinya jumlah etnis Batak Angkola-Mandailing yang besar tersebut dalam realitasnya tidak mampu mendominasi dalam praktik berbahasa seharihari khususnya siswa MTsN 2 Labuhanbatu Selatan. Besarnya jumlah orang Angkola-Mandailing dan signifikannya jumlah orang Jawa mendorong bahasa yang dipraktikkan oleh siswa-siswa tersebut Bahasa Indonesia sebagai jalan tengah dan juga berkat dukungan sistem pendidikan yang tentu lebih mendorong penggunaan Bahasa Nasional (Tondro, 2009). Studi ini melihat bagaimana gambaran siswa MTsN 2 Labuhanbatu Selatan mempraktikkan bahasa dalam interaksinya seharihari, baik dalam keluarga maupun pertemanan. Bahasa yang mereka praktikkan sehari-hari tentu tidak lepas dari apa yang mereka dapatkan 
dari keluarga sebagai lingkungan belajar pertama, sekolah sebagai lingkungan belajar formal dan komunitas masyarakat sebagai lingkungan belajar pendukung.

Jika kita fahami desentralisasi sebagai ruang menguatnya identitas etnis lokal (Kambo, 2015) seperti salah satunya penggunaan bahasa daerah. Dalam konteks Labusel ternyata hal tersebut tidak memberi pengaruh besar, yang terjadi justeru otonomi daerah yang telah berlangsung cukup lama justeru tidak memberi pengaruh signifikan pada penguatan identitas Lokal. Bahkan ruang otonomi daerah telah mendekatkan ruang-ruang gaya hidup urban merambah hingga ke pedesaan dan ini ditandai pula dengan melemahnya peran bahasa daerah yang dianggap sebagai pertanda kekolotan. Namun terlepas dari itu, identitas ambivalen yang dimiliki oleh masyarakat Labusel yakni sebagai orang Batak yang di bawah pengaruh Kesultanan Melayu Kota Pinang (Riyadi, 2013: 30-31) turut memberi ruang melemahnya otoritas kultural memaksa anggota masyarakatnya mempraktikkan bahasa daerah dalam keseharian. Sehingga tidak mengherankan jika bahasa daerah bukanlah menjadi bahasa ibu dalam masyarakat Labusel, peran bahasa daerah tak lebih menjadi bahasa kedua setelah bahasa nasional.

Melihat pergerseran penggunaan bahasa daerah tersebut, maka ada potensi hambatan dalam pengembangan masyarakat. Sebagai siswa MTs, dalam jangka panjang akan memegang peran penting dalam masyarakat. Dalam hal ini jika sejak masa sekolah menengah, penggunaan bahasa daerah tidak lagi menjadi bahasa ibu, maka ke depan budaya lokal tidak lagi dimiliki terutama oleh masyarakat Labuhanbatu Selatan. Budaya lokal yang merupakan budaya asli masyarakat setempat adalah dasar sekaligus isu sentral dalam pengembangan masyarakat yaitu untuk dipertahankan. Pengembangan masyarakat tidak boleh mengorbankan budaya lokal masyarakat setempat.

\section{Praktik Berbahasa dalam Tinjauan Multikulturalisme dan Community Development}

Dari berbagai literatur praktik berbahasa yang ditinjau, secara umum setidaknya dapat kita kelompokkan ke dalam tiga kategori, yang pertama terkait aspek etnisitas dalam berbahasa; kedua terkait peran bahasa dalam pendidikan karakter; dan yang ketiga terkait pergeseran dalam praktik berbahasa daerah yang berdampak pada praktik pengembangan masyarakat. 
Pertama, studi yang mengulas terkait aspek etnisitas dalam praktik berbahasa pada masyarakat yang multikulral. Tondro (2009) melihat bahwa kondisi masyarakat yang majemuk berkontribusi terhadap kepunahan-kepunahan bahasa lokal. Hal ini sebagai dampak masyarakat yang hidup dalam dua atau bahkan lebih bahasa tanpa bahasa ibu sehingga mendorong tidak terpeliharanya bahasa-bahasa daerah. Selain itu, dalam kondisi multi etnik dan multi bahasa mendorong setiap interaksi tidak menggunakan bahasa lokal, dan tentu dapat mendorong menguatnya bahasa yang lebih dominan dan terancamnya bahasa yang lebih minoritas. Bahasa Indonesia juga berkontribusi terhadap tergerusnya pemakain bahasa-bahasa daerah baik lewat jalur pendidikan, pemerintahan maupun dalam kontak dengan kelompok etnik yang berbeda. Sementara itu Sibarani (2013) melihat bahwa penggunaan bahasa suatu etnis dalam masyarakat majemuk dapat menguatkan sikap etnosentrisme dan memiliki potensi konflik antaretnis. Hal ini dilatari perbedaan warna berbahasa dan perbedaan nilai yang dianut. Sehingga diperlukan suatu strategi berkomunikasi yang mengedepankan sikap toleransi antaretnis dan saling menerima perbedaan nilai antaretnis.

Kedua, studi yang melihat peran bahasa dalam pendidikan karakter. Setyaningsih (2015) melihat bahwa terpinggirkannya bahasa Jawa dalam komunikasi sehari-hari anak-anak dapat melunturkan nilainilai luhur budaya Jawa yang secara tidak langsung juga berkontribusi pada lunturnya jati diri bangsa, karena bahasa daerah berperan penting dalam pembentukan karakter bangsa. Sehingga menjadi sangat penting pendidikan bahasa Jawa sejak dini dari lingkungan keluarga dan juga didukung lingkungan sekolah untuk senantiasa mengajarkan bahasa dan budaya Bangsa.

Sementara itu Laila (2016) melihat hubungan antara perilaku berbahasa dalam kaitannya dengan pembentukan kepribadian sangat erat. Laila melihat bahwa remaja yang konsisten menggunakan bahasa Jawa Krama berbanding lurus dengan tingkat konsistensinya dalam menjalankan syariat Islam. Hampir tidak berbeda dengan Laila, Solin (2010) juga melihat bahwa ada keterkaitan antara bahasa dengan karakter bangsa, dan Sastra Indonesia merupakan sumber nilai-nilai karakter bangsa, pemahaman bahasa yang baik memberi kontribusi pada karakter yang baik. Terkait hubungan bahasa dengan karakter dan kepribadian Hamzah dan Hassan (2011) melihat bahwa kepribadian dan kearifan-kearifan Melayu terkandung dalam pesan-pesan yang 
disampaikan lewat peribahasa Melayu.

Ketiga, studi yang memperlihatkan pergeseran penggunaan bahasa, khususnya pergeseran dari bahasa daerah kepada Bahasa Indonesia maupun terkait kontestasi antar bahasa daerah. Alamsyah, Taib, Azwardi dan Idam (2011) melihat bahwa kesulitan dalam pembelajaran bahasa daerah Aceh karena kecemasan orang tua pada anak-anaknya akan mengalami ketertinggalan khsususnya pelajaran di Sekolah. Kekhawatiran ini mengakibatkan orang tua enggan mengajarkan bahasa Aceh dan lebih memilih Bahasa Indonesia.

Sementara itu, Mardikantoro (2007) melihat bahwa pergeseran bahasa yang terjadi di Brebes menyangkut pola hubungan antara suami dengan isteri dan juga orang tua dengan anak. Hasil studi Mardikantoro memperlihatkan bahwa seorang suami yang Jawa cenderung mengikuti bahasa isterinya menggunakan bahasa yakni Sunda kasar, termasuk juga mengajarkannya dengan anak-anak. Ditambahkan pula bahwa pendidikan juga lebih mengarahkan anak-anak untuk mengutamakan penggunaan Bahasa Indonesia. Pergeseran Bahasa juga ditunjukkan oleh Mardikantoro (2012a) yang pertama pergeseran bahasa pada keluarga Samin dari Bahasa Jawa Ngoko kepada Bahasa Jawa Krama, hal ini dipengaruhi oleh perubahan perspektif masyarakat Samin terhadap bahasa, dari yang sebelumnya sebagai alat perlawanan menjadi alat komunikasi, sehingga harus yang lebih saling menghormati, hal ini juga merupakan bukti semakin terbukanya masyarakat Samin (Mardikantoro, 2012b).

Hal ini merupakan awal bagaimana pengembangan masyarakat tidak lagi berjalan sesuai prinsipnya karena tidak lagi mempertahankan budaya lokal. Menurut Mbete (2009) terlah terjadi "pemusnahan" bahasa lokal Nusantara dan terus berlanjut karena bahasa lain yang dianggap bergengsei, berjaya dan menguntungkan. Dalam hal ini, penggunaan bahasa nasional atau asing memang penting, namun tidak mengabaikan bahkan menelantarkan bahasa ibu dan bahasa lokal yang merupakan simbol majemuk bagi bangsa Indonesia. Sehingga diperlukan upaya pemberdayaan untuk menciptakan kondisi yang menghargai budaya lokal termasuk bahasa ibu. Salah satu yang dapat dilakukan yaitu peningkatan pemahaman billingual (bahasa nasional dan bahasa lokal).

Beberapa studi tersebut, menunjukkan bahwa keberadaan bahasa daerah berhadapan dengan Bahasa Indonesia. Keduanya merupakan bahasa yang penting, dalam kehidupan sehari-hari. Namun, dengan penggunaan Bahasa Indonesia yang lebih sering, terkadang menyebabkan 
bahasa daerah semakin ditinggalkan. Multikulturalisme, pluralisme, dunia pendidikan adalah beberapa hal yang dapat menyebabkan pergersaran bahasa daerah. Sehingga, hal tersebut yang menjadi pemabahasan utama dalam tulisan ini. Penggunaan bahasa daerah dan Bahasa Indonesia oleh siswa MTsN serta dinamikanya untuk melihat eksistensi bahasa daerah dalam jangka panjang.

\section{Metode Penelitian}

Penelitian ini merupakan suatu penelitian dengan pendekatan kualitatif yang dalam pengumpulan datanya menggunakan dua metode utama yakni dengan menyebarkan angket dan wawancara mendalam. Angket disebar kepada 94 siswa MTsN 2 Labuhanbatu Selatan yang terdiri dari 3 kelas yakni 1 kelas dalam setiap tingkatan. Rincian penyebaran angket antara lain 27 orang siswa kelas VII, 33 orang siswa kelas VIII dan 34 orang siswa kelas IX. Sedangkan jika dilihat dari aspek gender, maka siswa yang ditanyakan tersebut sebanyak 48 orang berjenis kelamin lakilaki dan 46 orang lainnya perempuan. Pertanyaan yang ditanyakan dalam angket tersebut antara lain (1) bahasa yang pertama kali diperkenalkan dan bahasa kedua yang diperkenalkan; (2) bahasa yang digunakan di lingkungan keluarga; (3) bahasa yang digunakan dalam pergaulan; serta (4) kemampuan menggunakan bahasa daerah di luar bahasa daerahnya sendiri.

Wawancara sendiri dilakukan kepada beberapa siswa MTsN 2 Labuhanbatu Selatan baik laki-laki maupun perempuan. Pemilihan informan didasarkan atas keterwakilan etnis, gender, tingkatan kelas dan juga prestasi akademik, siswa yang diwawancarai tersebut mewakili setidaknya lima etnis yakni Batak Angkola-Mandailing, Batak Toba, Jawa, Minangkabau dan juga Melayu. Informan yang dipilih keseluruhannya merupakan siswa yang tidak terlibat dalam menjawab pertanyaan angket dengan pertimbangan untuk melihat variasi informasi sekaligus mengkonfirmasi informasi yang dihasilkan dari angket yang telah disebar kepada siswa MTsN 2 Labuhanbatu Selatan.

\section{Hasil dan Pembahasan}

Berdasarkan penelitian yang dilakukan dengan metode penyebaran angket dan wawancara didapatkan beberapa data. Adapun data yang disajikan dikelompokkan ke dalam tiga kategori yakni, (1) data yang memperlihatkan proses pembelajaran bahasa dan pemahaman 
bahasa daerah; (2) data yang menunjukkan praktik penggunaan bahasa di lingkungan keluarga dan pertemanan; dan (3) data yang menunjukkan praktik multikuralisme dalam berbahasa. Berikut disajikan data berupa sejumlah tabel dan hasil wawancara dengan sejumlah informan.

\section{Proses Pembelajaran Bahasa dan Pemahaman Bahasa daerah}

Data yang disajikan dalam bagian ini merupakan tabel-tabel hasil penyebaran angket yang menggambarkan penggunaan bahasa utama berdasarkan etnis, kemampuan menggunakan bahasa daerah berdasarkan etnis dan waktu mengenal bahasa kedua juga dilihat dari sudut pandang etnis. Selain itu, terdapat sejumlah hasil wawancara dengan siswa MTsN 2 Labuhanbatu Selatan yang memperlihatkan proses pembelajaran bahasa daerah yang didapatkan oleh siswa tersebut.

Berikut data tentang bahasa pertama yang digunakan oleh siswa MTsN 2 Labuhanbatu Selatan:

Tabel 1. Penggunaan Bahasa Pertama Berdasarkan Etnis

\begin{tabular}{|c|c|c|c|c|c|c|c|}
\hline \multirow{3}{*}{ No. } & \multirow{3}{*}{ Suku } & \multicolumn{6}{|c|}{ Bahasa Pertama } \\
\hline & & \multicolumn{3}{|c|}{ Bhs daerah } & \multicolumn{3}{|c|}{ Bhs Indo } \\
\hline & & $\mathbf{L}$ & $\mathbf{P}$ & Jml & $\mathbf{L}$ & $\mathbf{P}$ & Jml \\
\hline 1. & $\begin{array}{l}\text { Batak Angkola- } \\
\text { Mandailing }\end{array}$ & - & 4 & 4 & 34 & 25 & 59 \\
\hline 2. & Batak Toba & - & - & - & 2 & 4 & 6 \\
\hline 3. & Batak Simalungun & - & - & - & 1 & 1 & 2 \\
\hline 4. & Batak Pakpak & - & - & - & - & 1 & 1 \\
\hline 5. & Melayu & - & 1 & 1 & - & - & - \\
\hline 6. & Minangkabau & - & - & - & 1 & - & 1 \\
\hline 7. & Jawa & 1 & 1 & 2 & 9 & 8 & 17 \\
\hline 8 & Banten & - & - & - & - & 1 & 1 \\
\hline & Total & 1 & 6 & 7 & 47 & 40 & 87 \\
\hline
\end{tabular}

Tabel 1 memperlihatkan bahwa siswa MTsN 2 Labuhanbatu Selatan umumnya menggunakan Bahasa Indonesia sebagai bahasa pertama yakni sebanyak 87 orang $(92,55 \%)$ berbanding 7 orang $(7,45 \%)$. Mayoritas pengguna Bahasa Indonesia sebagai bahasa pertama terjadi hampir di semua etnis, kecuali pada etnis Melayu sebanyak 1 orang dan ini juga dimungkinkan faktor dekatnya Bahasa Melayu dengan Bahasa Indonesia. Sementara itu, etnis Batak Angkola-Mandailing sebagai penduduk asli justru sebesar 93,65 \% yang menjadikan Bahasa Indonesia sebagai bahasa pertama, menariknya dari 4 orang Angkola-Mandailing yang menjadikan bahasa daerah sebagai bahasa pertama keseluruhannya berjenis kelamin 
perempuan.

Berikut data tentang kemampuan berbahasa daerah siswa MTsN 2 Labuhanbatu Selatan:

Tabel 2. Kemampuan Berbahasa daerah Berdasarkan Etnis

\begin{tabular}{|c|c|c|c|c|c|c|c|}
\hline \multirow[t]{2}{*}{ No. } & \multirow[t]{2}{*}{ Etnis } & \multicolumn{3}{|c|}{$\frac{\text { Bisa Berbahasa }}{\text { daerah }}$} & \multicolumn{3}{|c|}{$\frac{\frac{\text { Tidak Bisa }}{\text { Berbahasa }}}{\text { daerah }}$} \\
\hline & & $\mathbf{L}$ & $\mathbf{P}$ & Jml & $\mathbf{L}$ & $\mathbf{P}$ & Jm \\
\hline 1. & Batak Angkola-Mandailing & 34 & 29 & 63 & - & - & - \\
\hline 2. & Batak Toba & 2 & 4 & 6 & - & - & - \\
\hline 3. & Batak Simalungun & 1 & - & 1 & - & 1 & 1 \\
\hline 4. & Batak Pakpak & - & 1 & 1 & - & - & - \\
\hline 5. & Melayu & - & 1 & 1 & - & - & - \\
\hline 6. & Minangkabau & 1 & - & 1 & - & - & - \\
\hline 7. & Jawa & 9 & 7 & 16 & 1 & 2 & 3 \\
\hline \multirow[t]{2}{*}{8} & Banten & - & - & - & - & 1 & 1 \\
\hline & & 47 & 42 & 89 & 1 & 4 & 5 \\
\hline
\end{tabular}

Tabel 2 memperlihatkan bahwa walaupun bahasa daerah dijadikan sebagai bahasa kedua, namun mayoritas yakni 89 siswa (94,68 \%) dapat menggunakan bahasa daerah. Bahkan seluruh siswa yang beretnis Batak Angkola-Mandailing bisa berbahasa daerah termasuk pula etnis Batak Toba yang memang kedua etnis memiliki banyak kesamaan kosa kata. Sedangkan etnis Jawa sendiri terdapat 3 siswa $(15,79)$ yang tidak bisa berbahasa Jawa dan juga etnis Banten, hal ini dimungkinkan mereka tinggal dalam lingkungan perkampungan etnis Angkola-Mandailing.

Berikut data tentang waktu saat siswa MTsN 2 Labuhanbatu Selatan dalam mengenali bahasa kedua:

Tabel 3. Waktu Mengenal Bahasa Kedua Berdasarkan Etnis

\begin{tabular}{clcccccc} 
& & \multicolumn{6}{c}{ Usia Mengenal Bahasa Kedua } \\
\cline { 3 - 8 } No & Etnis & $\begin{array}{c}\mathbf{4 - 6} \\
\text { Thn }\end{array}$ & $\begin{array}{c}\mathbf{7 - 9} \\
\text { Thn }\end{array}$ & $\begin{array}{c}\mathbf{1 0}- \\
\mathbf{1 2}\end{array}$ & $\begin{array}{c}\text { Tdk } \\
\text { Tahu }\end{array}$ & $\begin{array}{c}\text { Hny 1 } \\
\text { Bhs }\end{array}$ & Jml \\
& & 12 & 41 & 6 & 4 & - & $\mathbf{6 3}$ \\
\hline 1. & $\begin{array}{l}\text { Batak Angkola- } \\
\text { Mandailing }\end{array}$ & & & & & &
\end{tabular}




\begin{tabular}{llcccccc} 
2. & Batak Toba & - & 3 & 2 & 1 & - & $\mathbf{6}$ \\
3. & Batak Simalungun & - & 1 & - & - & 1 & $\mathbf{2}$ \\
4. & Batak Pakpak & - & 1 & - & - & - & $\mathbf{1}$ \\
5. & Melayu & - & 1 & - & - & - & $\mathbf{1}$ \\
6. & Minangkabau & 1 & - & - & - & - & $\mathbf{1}$ \\
7. & Jawa & 2 & 10 & 1 & 3 & 3 & $\mathbf{1 9}$ \\
8 & Banten & - & - & - & - & 1 & $\mathbf{1}$ \\
\hline & Total & $\mathbf{1 5}$ & $\mathbf{5 7}$ & $\mathbf{9}$ & $\mathbf{8}$ & $\mathbf{5}$ & $\mathbf{9 4}$ \\
\hline
\end{tabular}

Tabel 3 memperlihatkan bahwa, umumnya siswa mengenal bahasa kedua pada rentang usia 7 hingga 9 tahun yakni sebanyak 57 siswa atau sekitar 60,64 \% dari siswa yang ditanyakan. Pada usia tersebut juga usia dimana anak-anak tersebut mulai memasuki jenjang Sekolah Dasar. Sedangkan siswa yang hanya mampu menggunakan satu bahasa saja terdapat 5 siswa atau sekitar 5,32 \% dari jumlah siswa. Dilihat dari latar belakang etnisnya dari 5 anak, 2 di antaranya merupakan etnis yang jumlahnya memang sangat sedikit di Labusel sendiri.

Sementara itu, berikut potongan wawancara dengan siswa MTsN 2 Labuhanbatu Selatan terkait proses pembelajaran Bahasa daerah mereka. Sebagaimana yang disampaikan oleh Fernandes (kelas VIII) menyampaikan "...di rumah pakai bahasa Padang, pertama sekali dikenalkan dengan bahasa padang, sejak masuk sekolah bisa bahasa Indonesia, dua-duanya penting..." ditambahkan pula oleh Lestari (Kelas VII) yang menyampaikan:

“...di rumah pakai Bahasa Jawa, mulai mengenal Bahasa Jawa sekitar usia 8 tahun, sebelumnya menggunakan Bahasa Indonesia, nenek menyuruh Bahasa Jawa, nenek cerita-cerita Bahasa Jawa..."

Sedangkan Dara (Kelas IX) etnis Angkola-Mandailing juga menyampaikan:

“...di rumah menggunakan bahasa campur, lebih sering Bahasa Indonesia, main-main di luar rumah bahasa indonesia, pertama Bahasa Indonesia sejak TK, Bahasa Kampung(Daerah) kelas 1 SD...”

\section{Praktik Penggunaan Bahasa dalam Lingkungan Keluarga dan Pergaulan}

Data yang disajikan berikut merupakan data hasil angket dan wawancara yang memperlihatkan praktik penggunaan bahasa baik di Lingkungan keluarga dan pergaulan. Untuk melihat penggunaan bahasa dalam keluarga berdasarkan etnis dapat dilihat dalam tabel 4 berikut: 
Tabel 4. Penggunaan Bahasa Dalam Keluarga Berdasarkan Etnis

\begin{tabular}{llccccc}
\hline No. & \multicolumn{1}{c}{ Etnis } & $\begin{array}{c}\text { Bhs } \\
\text { Indo }\end{array}$ & $\begin{array}{c}\text { Bhs } \\
\text { daerah }\end{array}$ & $\begin{array}{c}\text { Bhs Indo } \\
\text { dan } \\
\text { Daerah }\end{array}$ & $\begin{array}{c}\text { Bhs } \\
\text { daerah } \\
\text { lainnya }\end{array}$ & Jml \\
\hline 1. & $\begin{array}{l}\text { Batak Angkola- } \\
\text { Mandailing }\end{array}$ & 45 & 15 & 2 & 1 & $\mathbf{6 3}$ \\
2. & Batak Toba & 4 & - & - & 2 & $\mathbf{6}$ \\
3. & Batak & 1 & - & - & 1 & $\mathbf{2}$ \\
& Simalungun & & & & & \\
4. & Batak Pakpak & - & 1 & - & - & $\mathbf{1}$ \\
5. & Melayu & - & - & - & 1 & $\mathbf{1}$ \\
6. & Minangkabau & 1 & - & - & - & $\mathbf{1}$ \\
7. & Jawa & 16 & 3 & - & - & $\mathbf{1 9}$ \\
8 & Banten & 1 & - & - & - & $\mathbf{1}$ \\
\hline & Total & $\mathbf{6 8}$ & $\mathbf{1 9}$ & $\mathbf{2}$ & $\mathbf{5}$ & $\mathbf{9 4}$ \\
\hline
\end{tabular}

Jika diperhatikan tabel 4 maka akan terlihat bahwa dalam lingkungan keluarga siswa MTsN 2 Labuhanbatu Selatan 72,34 \% (68 siswa) yang menggunakan Bahasa Indonesia sebagai bahasa pengantarnya. Sementara yang menggunakan Bahasa daerah di lingkungan keluarganya hanya 20,21 \% (19 siswa). Dari 19 siswa tersebut, etnis Batak Angkola-Mandailing yang menggunakan Bahasa daerah di dalam keluarganya terdapat 15 siswa artinya 23,81\% siswa yang beretnis Batak Angkola-Mandailing yang berbahasa daerah atau 75,95 \% siswa yang menggunakan bahasa daerah di rumah adalah orang Batak AngkolaMandailing.

Sementara itu, penggunaan bahasa dalam pergaulan siswa MTsN 2 Labuhanbatu Selatan dapat dilihat dalam tabel 5 berikut:

Tabel 5. Penggunaan Bahasa Dalam Pergaulan Berdasarkan Etnis

\begin{tabular}{clccccc}
\hline No. & Etnis & $\begin{array}{c}\text { Bhs } \\
\text { Indo }\end{array}$ & $\begin{array}{c}\text { Bhs } \\
\text { daerah }\end{array}$ & $\begin{array}{c}\text { Bhs Indo } \\
\text { dan } \\
\text { Daerah }\end{array}$ & $\begin{array}{c}\text { Bhs } \\
\text { daerah } \\
\text { lainnya }\end{array}$ & Jml \\
\hline 1. & $\begin{array}{l}\text { Batak Angkola- } \\
\text { Mandailing }\end{array}$ & 55 & 6 & 2 & - & $\mathbf{6 3}$ \\
\end{tabular}




\begin{tabular}{llccccc} 
2. & Batak Toba & 5 & - & - & 1 & $\mathbf{6}$ \\
3. & Batak & 1 & - & - & 1 & $\mathbf{2}$ \\
& Simalungun & & & & & \\
4. & Batak Pakpak & 1 & - & - & - & $\mathbf{1}$ \\
5. & Melayu & 1 & - & - & - & $\mathbf{1}$ \\
6. & Minangkabau & 1 & - & - & - & $\mathbf{1}$ \\
7. & Jawa & 18 & - & 1 & - & $\mathbf{1 9}$ \\
8 & Banten & 1 & - & - & - & $\mathbf{1}$ \\
\hline & Total & $\mathbf{8 3}$ & $\mathbf{6}$ & $\mathbf{3}$ & $\mathbf{2}$ & $\mathbf{9 4}$ \\
\hline
\end{tabular}

Jika kita perhatikan tabel 5, data memperlihatkan bahwa sebagian besar siswa yakni $88,30 \%$ atau sebanyak 83 siswa yang menggunakan Bahasa Indonesia sebagai bahasa pergaulan sehari-harinya. Hanya terdapat 6 siswa $(6,38 \%)$ yang menggunakan bahasa daerah dalam pergaulannya dan itu juga seluruhnya siswa yang beretnis Batak AngkolaMandailing. Sementara terdapat 2 siswa (2,13 \%) yang menggunakan bahasa daerah etnis lain dalam bahasa pertemanannya dan 3 siswa $(3,19$ \%) yang menggunakan Bahasa Indonesia dan bahasa daerah dalam lingkungan pergaulannya.

Berikut wawancara terhadap siswa yang memperlihatkan bahasa yang digunakan dalam lingkungan keluarga dan pergaulan. Fadilah (Kelas VII) seorang siswa yang beretnis Mandailing menyampaikan "...di rumah menggunakan bahasa indonesia, kurang mengerti bahasa Mandailing, bermain di dekat rumah juga pakai Bahasa Indonesia, di sekolah juga pakai Bahasa Indonesia...". sementara itu Kurniawati (Kelas IX) yang beretnis Jawa menyampaikan:

“..di rumah bahasa indonesia, bisa sedikit bahasa Jawa, mamak menyuruh (memerintahkan) pakai bahasa Jawa...bisa bahasa jawa sejak kecil tinggal di lingkungan jawa, sama kawan-kawan menggunakan bahasa indonesia, tidak bisa berbahasa mandailing..."

Hal ini dapat diartikan bahwa penggunaan Bahasa Indonesia lebih sering dilakukan oleh siswa MTsN 2 Labusel baik dalam keluarga maupun pergaulan. Mereka menganggap bahasa daerah dan Bahasa Indonesia sama pentingnya. Dalam hal ini jumlah mayoritas penggunaan Bahasa Indonesia oleh siswa tidak bisa diartikan secara mutlak bahwa Bahasa Indonesia telah menghilangkan bahasa daerah. Hal ini disebabkan karena masih banyak juga siswa yang menggunakan bahasa daerah dalam keluarga dan pergaulan. 


\section{Praktik Multikuluralisme dalam Berbahasa}

Data-data yang disajikan dalam bagian ini yang menggambarkan praktik multikulturalisme dalam berbahasa, data yang diperlihatkan dinamika praktik berbahasa dan kemampuan berbahasa daerah di luar etnis sendiri. Berikut data tentang dinamika praktik berbahasa siswa MTsN 2 Labusel:

Tabel 6. Dinamika praktik berbahasa

\begin{tabular}{|c|c|c|c|c|}
\hline No. & $\begin{array}{c}\text { Bahasa } \\
\text { Keluarga }\end{array}$ & Bahasa Pergaulan & Jumlah & $\begin{array}{l}\text { Persen } \\
(\%)\end{array}$ \\
\hline 1. & Bahasa Indonesia & Bahasa Indonesia & 62 & 65,96 \\
\hline 2. & Bahasa Indonesia & Bahasa daerah & 4 & 4,26 \\
\hline 3. & Bahasa Indonesia & Bahasa Campuran & 3 & 3,19 \\
\hline 4. & Bahasa daerah & Bahasa Indonesia & 18 & 19,15 \\
\hline 5. & Bahasa daerah & Bahasa daerah & 1 & 1,06 \\
\hline 6. & $\begin{array}{l}\text { Bahasa } \\
\text { Campuran }\end{array}$ & Bahasa Indonesia & $\mathbf{1}$ & 1,06 \\
\hline 7. & $\begin{array}{l}\text { Bahasa daerah } \\
\text { Lainnya }\end{array}$ & Bahasa Indonesia & 3 & 3,19 \\
\hline 8. & $\begin{array}{l}\text { Bahasa daerah } \\
\text { Lainnya }\end{array}$ & $\begin{array}{l}\text { Bahasa } \\
\text { Lainnya }\end{array}$ & 2 & 2,13 \\
\hline & Total & & 94 & 100,00 \\
\hline
\end{tabular}

Tabel 6 memperlihatkan bahwa, 62 siswa (65,96 \%) yang menggunakan Bahasa Indonesia baik di lingkungan keluarga maupun di lingkungan pertemanan. Sedangkan 18 siswa (19,15 \%) yang menggunakan Bahasa daerah di rumah tetapi menggunakan Bahasa Indonesia di lingkungan teman-temannya. Sementara itu, terdapat 7 siswa $(7,45 \%)$ yang menggunakan Bahasa Indonesia di rumah tetapi menggunakan Bahasa daerah maupun campuran dalam pergaulannya. Sementara yang konsisten dengan penggunaan Bahasa daerah hanya 1 siswa saja. Untuk melihat kemampuan berbahasa daerah lain dapat dilihat dalam tabel 7 berikut.

Tabel 7. Kemampuan Berbahasa daerah lain Berdasarkan Etnis dan Gender

\begin{tabular}{|c|c|c|c|c|}
\hline No & Etnis & Bisa & $\begin{array}{c}\text { Tidak } \\
\text { Bisa }\end{array}$ & Keterangan \\
\hline 1. & $\begin{array}{l}\text { Batak Angkola- } \\
\text { Mandailing }\end{array}$ & 12 & 51 & $\begin{array}{l}12 \text { orang siswa }(19,05 \\
\%) \text { etnis Mandailing }\end{array}$ \\
\hline
\end{tabular}




\begin{tabular}{|c|c|c|c|c|}
\hline & & & & bisa berbahasa Jawa \\
\hline \multirow[t]{8}{*}{2.} & Batak Toba & 3 & 3 & $1 \quad$ orang \\
\hline & & & & Berbahasa Jawa 1 \\
\hline & & & & Siswa, 2 siswa \\
\hline & & & & diantaranya \\
\hline & & & & berbahasa Angkola- \\
\hline & & & & $\begin{array}{l}\text { Mandailing, dalam } \\
\text { studi ini Bahasa Toba }\end{array}$ \\
\hline & & & & dan Angkola- \\
\hline & & & & $\begin{array}{l}\text { Mandailing dianggap } \\
\text { berbeda. }\end{array}$ \\
\hline \multirow[t]{7}{*}{3.} & Batak Simalungun & 2 & - & 1 orang siswa bisa \\
\hline & & & & berbahasa Jawa, 1 \\
\hline & & & & lainnya bisa berbahasa \\
\hline & & & & Angkola-Mandailing, \\
\hline & & & & $\begin{array}{l}\text { dalam studi ini Bahasa } \\
\text { Simalungun dan }\end{array}$ \\
\hline & & & & Angkola-Mandailing \\
\hline & & & & dianggap berbeda. \\
\hline 4. & Batak Pakpak & - & 1 & - \\
\hline \multirow[t]{3}{*}{5.} & Melayu & 1 & - & 1 orang siswa bisa \\
\hline & & & & berbahasa Angkola- \\
\hline & & & & Mandailing \\
\hline 6. & Minangkabau & - & 1 & - \\
\hline \multirow[t]{4}{*}{7.} & Jawa & 5 & 14 & $5 \quad$ orang \\
\hline & & & & $(26,32 \%) \quad$ beretnis \\
\hline & & & & Jawa bisa berbahasa \\
\hline & & & & Angkola-Mandailing \\
\hline \multirow[t]{4}{*}{8} & Banten & - & 1 & - \\
\hline & Total & 23 & 71 & $24,47 \%$ dari siswa \\
\hline & & & & dapat berbahasa di \\
\hline & & & & $\begin{array}{l}\text { luar banasa } \\
\text { daerahnya sendiri }\end{array}$ \\
\hline
\end{tabular}

Tabel 7 memperlihatkan bahwa hanya 23 siswa (24,47 \%) yang memiliki kemampuan menggunakan Bahasa daerah di luar Bahasa daerahnya sendiri, selebihnya siswa MTsN 2 Labuhanbatu Selatan tidak bisa berbahasa di luar Bahasa daerah etnisnya sendiri. Etnis Jawa sebagai etnis pendatang terbesar memiliki porsi yang cukup besar yang mampu menggunakan Bahasa daerah Batak Angkola-Mandailing yakni 26,32 \%, jika kita sederhanakan 1 dari 4 siswa beretnis Jawa mampu menggunakan dan memahami bahasa Batak Angkola-Mandailing. Sedangkan siswa 
beretnis Batak Angkola-Mandailing juga memiliki jumlah yang signifikan dalam memahami bahasa di luar etnisnya, yakni 19,05 \% atau hampir 1 dari 5 anak bisa berbahasa Jawa.

Berikut data wawancara yang memperlihatkan praktik multikulturalisme berbahasa, seperti Nuraisyah (Kelas IX) yang beretnis Batak Angkola-Mandailing menyampaikan:

“...di rumah bahasa campur, lebih sering Bahasa Indonesia, mainmain di luar rumah Bahasa Indonesia, bisa Bahasa Mandailing sejak SD, Bahasa Mandailing belum merasa perlu Bahasa Mandailing, Mamak (Ibu) menyuruh Bahasa Indonesia..."

Sementara Andrean (Kelas IX) yang beretnis Batak AngkolaMandailing menambahkan

“...di rumah pake bahasa Indonesia, bahasa Mandailing ga pala, bisa sikit-sikit, mamak kalau menyuruh (memerintahkan) Pake Bahasa Indonesia, ayah juga....tapi Bahasa Mandailing perlu lah, Bahasa Jawa pun bisa dikit..."

\section{Penguatan Institusi Sosiokultural}

Institusi sosiokultural memiliki peran penting dalam menjaga keberlanjutan suatu bahasa, institusi sosiokultural yang kuat dapat memaksa anggota masyarakat untuk terus mempraktikkan bahasa daerah. Tanpa didukung institusi yang sosiokultural yang kuat sulit rasanya mewujudkan kemampuan berbahasa daerah yang baik terutama dalam masyarakat yang multikultural (Tondro, 2009) bahkan ketidaksiapan institusi sosiokultural tersebut dapat mengancam kepunahan Bahasa daerah. Data memperlihatkan bahwa terdapat 5,32 \% yang sama sekali tidak bisa menggunakan Bahasa daerah, memang dapat kita katakan angka tersebut merupakan angka yang tidak signifikan, namun dalam masyarakat yang bukan berciri perkotaan angka sebesar $5,32 \%$ tersebut sebagai bentuk peringatan kepada kita bahwa, generasi kita semakin menjauh dari bahasa daerah kita.

Bekerja aktifnya institusi sosiokultural tentu akan mampu mendekatkan anak-anak terhadap pengetahuan sosial dan budayanya. Menempatkan anak-anak sebagai subyek dalam ritus-ritus adat akan memberikan pengalaman berharga bagi anak-anak untuk mengenali jati diri sosial budayanya (Setyaningsih,2015). Jika kita perhatikan data hasil angket yang memperlihatkan bahwa 92,55 \% anak-anak menggunakan Bahasa Indonesia sebagai Bahasa Ibu ditambah pula 88,30 \% yang menggunakannya sebagai bahasa pergaulan. Data ini mengindikasikan 
bahwa institusi sosiokultural tidak memberikan dukungan yang kuat terhadap pengembangan Bahasa daerah. Padahal sejatinya Bahasa daerah adalah wahana yang baik dalam penanaman nilai-nilai budaya dan penguatan jati diri bangsa (Setyaningsih, 2015). Sehingga cukup mengkhawatirkan bagi kita jika generasi tidak mampu menguasai dan memahami Bahasa Ibunya sendiri yang artinya menjauhkan anak-anak dari nilai-nilai kulturalnya.

Berbicara penguatan institusi sosiokultural, sudah seharusnya para pemangku kepentingan baik di tingkat komunitas, pemerintah dan kalangan pendidikan untuk merevitalisasi perannya dengan mengambil peluang dalam era otonomi daerah yang memberi ruang yang luas untuk itu (Kombo, 2015). Sudah seharusnya ritus-ritus adat dikenalkan ulang kepada generasi sembari mengenalkan nilai-nilai dan falsafah yang tertanam dalam kehidupan sosial budayanya. Jika hal ini dapat terlaksana, bukan saja persoalan bahasa yang mampu di atasi menguatnya peran institusi sosiokultural memberi ruang yang lebih dominan kepada komunitas untuk bersama-sama memberi kontrol terhadap perilaku generasi kita. Penguatan institusi sosiokultural sebagai sebuah proses reproduksi identitas, dimana berbeda dengan proses produksi yang didominasi oleh negara maka proses reproduksi menjadikan masyarakat berperan aktif dalam menghadirkan masa silam dalam rangka memperkuat identitas (Sofyan, 2020). Sehingga reproduksi ini nantinya akan melahirkan kewibawaan institusi sosiokultural tersebut, yang akan tampak pada sejauh mana adat itu dijadikan sebagai basis nilai masyarakat dalam menjalani kehidupannya sehari-hari.

\section{Promosi dan Penguatan Posisi Tawar Bahasa daerah}

Dalam pergaulan sehari-hari penggunaan Bahasa Indonesia maupun bahasa daerah lazim dipergunakan secara bersamaan, kedua bahasa dipandang memiliki nilai yang sama. Bahkan data memperlihatkan bahwa terjadi pergeseran yang cukup signifikan dalam penggunaan bahasa daerah yaitu terdapat 18 dari 19 anak yang menggunakan bahasa daerah di keluarga kemudian menggunakan Bahasa daerah dalam pertemanannya, artinya $94,74 \%$ anak tersebut tidak lagi menggunakannya dalam komunitasnya. Sedangkan yang sebaliknya 
hanya 4 anak saja yang berubah dari Bahasa Indonesia kepada bahasa daerah dari sebelumnya 68 anak, artinya hanya sekitar 5,88\% saja yang berubah. Data ini memperlihatkan bahwa posisi tawar bahasa daerah benar-benar lemah. Tidak hanya itu, anak-anak yang diwawancarai seperti Nurasyiah (Kelas IX) yang menyampaikan bahwa bahasa daerah memang belum perlu "...bahasa mandailing belum perlu...mamak menyuruh bahasa indonesia...”

Senada dengan itu, lingkungan sekolah juga tidak memberi ruang kepada siswa untuk menggunakan bahasa daerahnya. Justeru penggunaan bahasa daerah mendorong anak-anaknya tertinggal dalam hal mata pelajaran. Orang tua juga merasa bahwa bahasa daerah tidak mendukung prestasi anak-anak mereka (Alamsyah dkk, 2011). Namun jika kita lihat konteks masyarakat Labusel, yang direpresentasikan etnis Batak AngkolaMandailing sebagai etnis tempatan dan juga mayoritas, ternyata dalam praktik berbahasanya tidak memperlihatkan mereka sebagai mayoritas. Walaupun kita lihat bahwa etnis pendatang utama yakni Jawa yang mampu menggunakan Bahasa Angkola-Mandailing sebesar 26,32 \%, tetapi angka tersebut dalam praktiknya tidak berlaku artinya keadaan ini tidak memperlihatkan persegesaran bahasa sebagaimana yang dikemukakan Mardikantoro (2012b). Bahkan 71,43 \% orang AngkolaMandailing tidak menggunakan bahasanya sendiri di lingkungan keluarganya. Hal ini menegaskan kembali apa yang terjadi di Aceh (Almsyah dkk, 2011) terkait tidak percaya dirinya orang tua kepada bahasa daerahnya sendiri.

Upaya untuk mengembalikan bahasa daerah sebagai bahasa ibu dalam masyarakat dapat dimulai dari dunia pendidikan. Banyak kegiatan yang dapat mendukung dan melestarikan bahasa daerah seperti lomba bercerita dan menulis kembali cerita rakyat, mite, dongeng, legenda di daerahnya dalam bahasa daerah pada jenjang SMP/SMA, lomba cipta lagu bersyairkan bahasa-bahasa lokal. Beberapa kegiatan tersebut merupakan contoh pemberdayaan secara terpadu yang dapat dilakukan (Mbete, 2009). Hal ini dapat menjamin eksistensi bahasa daerah, dan pemberdayaan sejak dalam dunia pendidikan maupun dalam masyarakat.

\section{Melahirkan Teladan Berbahasa Daerah Sebagai Penguatan Community Development}

Pembiasaan berbahasa tentu tidak bisa dilepaskan dari siapa yang menjadi panutan, baik di ruang domestik maupun di ruang publik. Pada 
ranah domestik, hasil angket memperlihatkan bahwa siswa MTs Negeri Sungai Kanan umumnya menggunakan Bahasa Indonesia sebagai bahasa sehari-hari. Hal ini memperlihatkan bahwa di dalam lingkungan keluarga tidak memiliki teladan yang menjadikan bahasa daerah sebagai bahasa pengantar utama dalam keseharian (Setyaningsih, 2015).

Sementara itu penggunaan bahasa di ruang publik dapat kita klasifikan setidaknya dua lingkungan yakni lingkungan formal dan lingkungan informal. Dalam lingkungan formal seperti lingkungan pendidikan dan pemerintahan dalam konteks tertentu perlu ditekankan perlunya penggunaan dan pengenalan bahasa daerah. Dalam konteks pemerintahan, pengenalannya dapat dilakukan dengan penggunaan dua bahasa dalam papan informasi dan atau penggunaan bahasa daerah pada hari-hari tertentu. Bahkan bila perlu di tingkat desa, perlu pemberian istilah-istilah lokal dalam jabatan-jabatan desa. Sedangkan dalam konteks pendidikan, pembelajaran Bahasa daerah perlu diajarkan dalam mata pelajaran muatan lokal. Terkait Labusel sebagai daerah yang multikultural memang perlu pendekatan khusus, dalam materinya dapat diajarkan tergantung konteks etnis mayoritas peserta didiknya.

Hal ini juga dapat dilakukan misalnya dalam masyarakat yang mayoritas beretnis Jawa diajarkan muatan lokal bahasa Jawa dan begitu juga sebaliknya dengan etnis lain sembari mengenalkan pengetahuan dasar bahasa-bahasa etnis yang ada di Labusel sebagai apresiasi terhadap budaya lokal (Kambo,2015). Jika hal ini dilakukan maka akan membuat lembaga pendidikan dapat juga mempertahankan bahasa dareah. Dalam jangka panjang, praktik penggunaan Bahasa Indonesia tidak lagi semakin menggeser posisi bahasa daerah. Artinya muatan lokal dalam bentuk bahasa daerah dapat menjadi penyeimbang dalam posisi berbahasa sehari-hari.

Dalam lingkungan informal, dapat kita kelompokkan dalam dua kategori yakni lingkungan pertemanan dan tempat-tempat umum. Dalam lingkungan pertemanan, penggunaan bahasa yang utamanya adalah bahasa Indonesia sedangkan pada tempat-tempat umum biasanya bahasa yang berlaku menggunakan bahasa campuran. Perlu dikenalkan bahasa daerah lewat duta-duta bahasa, misalnya penggunaan campuran dalam pemberian informasi publik dan dalam iklan layanan masyarakat sehingga bahasa daerah semakin dikenal dan lebih sering digunakan.

Dalam konsep community development menurut Ife dan Tesoriero 
(2008) bahwa melestarikan budaya lokal adalah isu sentral karena dua alasan. Pertama klaim istimewa yang dimiliki masyarakat lokal terhadap daerah dan struktur komunitas trasidisional. Kedua, banyak kerugian telah dilakukan, yang mengorbankan masyarakat lokal atas nama community development. Dalam pengertian ini bahasa derah merupakan salah satu dari budaya lokal. Keberadaan bahasa daerah sudah sepatutnya untuk dilestarikan. Jika dalam ruang pendidikan hal ini dapat di lakukan, maka masyarakat lokal tidak lagi kehilangan bahasa daerahnya.

\section{Kesimpulan}

Studi ini memperlihatkan bahwa pembelajaran bahasa daerah tidak dilakukan oleh institusi-intitusi yang seharusnya memiliki andil lebih besar pada keluarga, otoritas adat dan atau lembaga pendidikan. Peran pembelajaran bahasa daerah kemudian diambil alih oleh peranperan informal seperti pasar, jalanan, teman permainan dan lain sebagainya. Proses yang berlangsung secara sporadis ini memberi anakanak kemampuan berbahasa daerah yang cukup fasih. Namun kemampuan berbahasa daerah yang fasih ini tidak diikuti oleh kemampuan menangkap makna dan nilai yang terkandung dalam bahasa daerah yang dipraktikkan. Akhirnya anak-anak menggunakan bahasa daerah hanya sekedar alat berkomunikasi, mereka melupakan bahwa dalam bahasa tadi ada makna-makna yang luas menyangkut tata krama, keteladanan dan pesan-pesan moral dari bahasa daerah tersebut. Dalam jangka panjang hal ini menjadi ancaman untuk kegiatan community development. Sehingga di satu sisi bahasa daerah menjadi dasar pengembangan masyarakat dan di sisi lain menjadi isu sentral untuk tidak boleh ditinggalkan.

\section{Daftar Pustaka}

Alamsyah, T., Taib, R., Azwardi \& Idham, M. (2011). Pemilihan Bahasa Indonesia Sebagai Bahasa Pertama Anak Dalam Keluarga Masyarakat Aceh Penutur Bahasa Aceh Di Nanggroe Aceh Darussalam (Choosing Indonesian As The First Language For Children For Achehnese Native Speaker In Achenese Family In Nanggroe Aceh Darussalam). Jurnal Pendidikan Bahasa Melayu, Malay Language Journal Education. Volume 1, Bil 2. Hal.: 31-44. http://spaj.ukm.my/ipbm/index.php/ipbm/article/view/28

Ali, M. (2016). Komunikasi Antar Budaya Dalam Tradisi Agama Jawa. 
Jakarta: Pustaka Ilmu Grup.

http://e-repository.perpus.iainsalatiga.ac.id/1807/

Hamzah, Z.A.Z. \& Hassan A.M. (2011). Bahasa Dan Pemikiran Dalam Peribahasa Melayu. Gema Online Journal of Language Studies. Volume 11 (3).

https://ejournal.ukm.my/gema/article/view/40

Ife, J \& Tesorieoro, F. (2008). Community Development: Alternatif Pengembangan Masyarakat di Era Globalisasi. Yogyakarta: Pustaka Pelajar.

Kambo, G.A. (2015). Etnisitas dalam Otonomi Daerah, Ethnicity in Regional Autonomy. The POLITICS: Jurnal Magister Ilmu Politik Universitas Hasanuddin. Volume 1, No. 1. https://journal.unhas.ac.id/index.php/politics/article/view/125

Laila, W.N. (2016). Konsep Diri Remaja Muslim Pengguna Bahasa Jawa Krama. Profetik Jurnal Komunikasi. Volume 09, No. 02, Hal.: 61-69. https://doi.org/10.14421/pjk.v9i2.1206

Mardikantoro, H,B. (2007). Pergeseran Bahasa Jawa Dalam Ranah Keluarga Pada Masyarakat Multibahasa Di Wilayah Kabupaten Brebes. Humaniora. Volume 19, No. 1, Hal.: 43-51. https://doi.org/10.22146/ih.890

Mardikantoro, H. B. (2012a). Bentuk Pergeseran Bahasa Jawa Masyarakat Samin Dalam Ranah Keluarga. Litera. Volume 11, No.2, Hal.: 204215. https://doi.org/10.21831/ltr.v11i2.1062

Mardikantoro, H. B. (2012b). Pilihan Bahasa Masyarakat Samin Dalam Ranah Keluarga. Humaniora. Volume 24, No.3, Hal.: 345-357. https://doi.org/10.22146/jh.1376

Mbete, A.M. (2009) Bahasa Dan Budaya Lokal Minoritas: Asalmuasal, Ancaman Kepunahan, dan Ancangan Pemberdayaan Dalam Kerangka Pola Ilmiah Pokok Kebudayaan. In Pemikiran Kritis Guru Besar Universitas Udayana: Bidang Sastra \& Budaya (pp 83-110). Denpasar: Udayana University Press \& Badan Penjamin Mutu Universitas Udayana (BPMU).

Rasimin. (2016). Pengembangan Karakter Multikultural Mahasiswa Dalam Pembelajaran Civic Education (Studi Pada Mahasiswa Jurusan 
KPI Fakultas Dakwah IAIN Salatiga). Inject, Interdisciplinary Journal of Communication, Vol. 1, No. 2. Hal: 145-164. https://doi.org/10.18326/inject.v1i2.145-164

Riyadi, A. (2013). Takko-takko Mata Pada Masyarakat AngkolaMandailing. Bandung: FISIP Universitas Padjadjaran. (Skripsi).

Setyaningsih, N,R. (2015). Pengenalan Bahasa Jawa Pada Anak Sebagai Bentuk Pemberdayaan Bahasa Lokal Dan Upaya Penguatan Jatidiri Bangsa. Jurnal Tutur. Volume 1,N0. 1, Hal.: 27-36.

Sibarani, B. (2013). Bahasa, Etnisitas dan Potensinya Terhadap Konflik. Jurnal Tittle. Hal. : 1-11. http://digilib.unimed.ac.id/id/eprint/998

Sofyan, M.A. (2020). Eksistensi Megono Sebagai Identitas Kultural: Sebuah Kajian Antropologi Kuliner Dalam Dinamika Variasi Makanan Global. Sosiologi Reflektif, Volume 15, No. 1, Hal: 45-62. http://ejournal.uinsuka.ac.id/isoshum/sosiologireflektif/article/view/1751/1451

Solin, M. (2010). Peranan Bahasa Indonesia Dalam Membangun Karakter Bangsa. Jurnal Bahasa. Volume 20 (03). ttp://digilib.unimed.ac.id/id/eprint/478

Tondro, F, H. (2009). Kepunahan Bahasa-bahasa daerah: Faktor Penyebab Dan Implikasi Etnolinguistik. Jurnal Masyarakat \& Budaya. Volume 11,No.2, Hal.: 278-296. https://doi.org/10.14203/jmb.v11i2.245

\section{Wawancara :}

Wawancara dengan Andrean, 19/02/2019

Wawancara dengan Dara, 19/02/2019

Wawancara dengan Fadhilah, 15/02/2019

Wawancara dengan Fernandes, 18/02/2019

Wawancara dengan Kurniawati, 19/02/2019

Wawancara dengan Lestari, 15/02/2019

Wawancara dengan Nuraisyah, 19/02/2019 